\title{
Research on the Predicament and Countermeasure of "Agriculture Co-operation System" in Chongzhou
}

\author{
Wenli Deng \\ School of Political Science and Public Administration \\ University of Electronic Science and Technology of China \\ Chengdu, China
}

\begin{abstract}
This paper analyzes the development conditions and characteristics of the "agricultural co-operation system". And the core of this system is the land management rights shares cooperatives in Chongzhou. It reveals the problems during the development, and puts forward the suggestions to promote the further improvement of the "agricultural cooperation" in Chongzhou.
\end{abstract}

Keywords-agricultural co-operation system; characteristics; problems; countermeasures

\section{INTRODUCTION}

The report of the 18th National Congress of the Communist Party of China made it clear that we should adhere to and improve the basic management system of rural areas, develop various forms of scale management, cultivate new business entities, and build a new agricultural economic system with intensification, professionalization, systematization and socialization. Land joint-stock cooperative is an important part of the main body of new agricultural production and management. And it is an innovation in the form of rural economic organization, both to protect the basic land rights and interests of farmers, but also to promote the industrialization of agriculture, largescale development.

Chongzhou, Sichuan province is located in the beautiful and fertile Chuanxi Plain, and is also one of the major food producing areas. While protecting the most basic land rights and interests of farmers, the goverment of Chongzhou actively promotes the innovation of the rural land management system, makes full use of land contract management right to verify the results. In the country, the government of Chongzhou firstly explores to establish the land management rights shares cooperatives to solve the agricultural problems that who will operate the cooperatives. On this basis, it constructs the "agricultural co-operation system" model with the farmers as the core subject, the agricultural professional managers, the land management right shares cooperatives and the social service organizations. In the end, it would achieve the appropriate scale of agriculture management and improve land production efficiency.

\section{DEFINITION OF RELATED CONCEPTS}

\section{A. The Separation of Rural Ownership Rights, Contract Rights and Management Rights}

It separates rural ownership rights, contract rights, and management rights. And these three rights are paralleled [1]. Among them, the collective ownership is fundamental. And the contract right of farmer is the foundation. The land management right is the key. And these three rights are collected in the rural basic management system.

\section{B. Land Management Rights Shares Cooperatives}

Land management right joint-stock cooperatives refer to that the farmers become the shareholders, and the land management rights become the equity. In the premise of having the right and license, farmers join the stock cooperatives with quantifying the land management rights. The cooperatives cultivate and manage the land in unitive standard. And the income of land management is distributed to the members of the cooperatives according to the shares after deducting the necessary collective accumulation.

\section{Agricultural Professional Managers}

Agricultural professional managers operate and manage the resources and capital in agriculture production and management. Agricultural professional managers assist the agricultural enterprises or owners to seek the greatest economic benefits. At the same time, they get the commission or bonus from the customers. And they have agricultural skills, which are similar to the professional managers in modern industrial and commercial enterprises.

\section{Agricultural Co-operation System}

Agricultural co-operation system refers to the "three-inone" agricultural business model. Since 2010, the government of Chongzhou has explored the "land management rights cooperatives + agricultural professional managers + modern agricultural service system" in practice. Farmers as the main body voluntarily set up land management rights shares cooperatives to promote the scale of agriculture management. To cultivate the agricultural professional managers is to promote the professional management of agriculture. To strengthen social service is to promote the organization and management of agriculture. And this is a new type of agricultural management. 


\section{The CharaCteristics OF "AgRicultural CO - OPERATION SYSTEM" IN CHONGZHOU}

In Chongzhou, the core of "agricultural co-operation system" is the family contract right as the basis, farmers as the main body. And the land management rights shares cooperatives, agricultural professional managers, social service organizations and other subjects would operate it. In the concept of rural basic management system, it develops the agricultural co-operation system. And in this system, it adheres to and implements the collective ownership right, stability and strengthen the farmers' contract right, release and revitalize the land management rights, cracked the problems that who will operate", "Who will grow "," Who will serve ". In the end, it achieves to construct, operate, share and win these cooperatives by multiple subjects [2].

\section{A. Intensive Management}

The land management right in the system of "agricultural co-operation" mainly adopts the unified operation. Specifically, the farmers are in accordance with the principle of voluntary community, social freedom, benefit sharing, and risk sharing. And it makes the valuation of the land management rights. And then they use these capitals to have equities. It set up the land management rights shares cooperatives. The lands in the community are operated by the cooperatives for unified farming and intensive management. And it is to solve the problem that who will operate the cooperatives.

As a cooperative member, the farmer is the actual decision maker and controller of the cooperative. They participate in the election of the council and the board of supervisors, the arrangement of the agricultural production plan, the cost budget and the formulation of the profit distribution plan, and also bear the cost of production.

The council is on behalf of all members of the cooperative. And it openly recruits agricultural professional managers, signs an operating contract that rules the production indicators, production costs, compensation provisions, etc. And it operates in agricultural production standards and quality standards of "unified procurement, unified planting, unified management and harvest, unified distribution. Cooperative and professional managers implement the distribution way of benefit-sharing, risksharing. In practice, it has taken the distribution way of overproduction, pure profit sharing and insurance dividends and other different distribution [3].

\section{B. Professional Managers}

Large-scale production and management of land can not be separated from the professional managers. The government of Chongzhou draws on the management system of modern enterprises, and then build an operating mechanism that land shares cooperatives + agricultural professional managers.

The government of Chongzhou cultivates the persons who meet the selection criteria, are willing to engage in agricultural management personnel. And then it will make the professional managers training. The persons who pass through the assessment of the examination would get the unified qualification certificate of agricultural professional manager. The agricultural professional managers who obtain the qualification certificates sign the employment contract with the cooperatives through the competition. And this conduct is signed with the production index, the cost control and the reward compensation. And the agricultural professional managers will manage the production in an unified standard. They report the production plan and the cost of production to the cooperative council. After the representatives of the members adopt the plan, it will carry out this plan. And it should show revenue and distribution in public timely. And the agricultural professional managers should accept the supervision from the members and the council.

According to establish and train the competitive professional managers who have knowledge and good management skills, understand technology, the government of Chongzhou solves a problem that the ones who have farming and the way how to make farming scientifically. It promotes the selection and application of seed selection, soil testing and fertilization, agricultural machinery technology and scientific results, which not only greatly reduces the input of means of production, but also greatly improves the efficiency of agricultural production.

\section{Socialization of the Service System}

The operation and management of land management rights shares cooperatives can not be separated from the support of agricultural social service system. The government of Chongzhou adheres to the development ideas of the government's guidance, the main body of the company, integration of resources, market operation, technical support and one-stop service. It builds a new agricultural socialized service system with public services, business services, special services and integrated services.

The new agricultural social service system can be divided into four parts. The first is science and technology service system. The government of Chongzhou promotes the local academy of agricultural sciences to cooperate with these cooperatives. And the results of agricultural scientific researches can be applied to the agricultural production timely. The second is the production and marketing service system. It needs to establish a service supermarket through the e-commerce platform, make the integration of pesticides, fertilizers, agricultural machines and other means of production and agricultural supply and demand information for the cooperative services. The third is the brand service system. It needs to create the brand of "The farming of Chongzhou". And it promotes the individual brand with the public agricultural product brand. And then it will promote agricultural standardization and the construction of brand. The fourth is the financial service system. It should develop the implementation of rural property mortgage financing pilot. And it needs to establish the rural property rights trading center. And the establishment of Shu Xing rural property mortgage financing guarantee company, the establishment of risk funds and the improvement of the 
relevant supporting policies can provide the financing services for large-scale operations.

\section{The DilemMa of PRACTICING IN AgRiCULTURE IN CHONGZHOU}

In Chongzhou, the agriculture co-operation system cracks the problems that the people who will run, who will make farming and who will serve. And it effectively improves the specialization and standardization of the large-scale agricultural production. And it promotes the transformation of agricultural development, achieves the efficiency of agriculture. In the end, it increases the farmers' income. However, lacking of the talents and financing difficulties, the further development of the agricultural co-operation system in Chongzhou has encountered two problems.

\section{A. Difficulty in Financing}

The majority of the funds of rural land management rights shares cooperatives are from the members' contributions and the public accumulation of cooperatives. In addition, it also includes the subsidies of the government, the community's donations to cooperatives and other legitimate income of cooperatives.

Compared with the traditional decentralized farmers, the cooperatives demand more funds. In addition to the purchase of seeds, pesticides, fertilizers and labor costs and other traditional capital needs, the cooperatives' needs are also concentrated in the purchase of agricultural machinery and seasonal grain purchasing and the cost of storage, and so on. According to the survey of Agricultural Development Bureau of Chongzhou in 2015, the funding needs of land shares cooperatives is 40 million yuan, involving about 80 cooperatives. Such a large demand for funds is difficult to solve by the cooperatives. And it needs the supports of the financial institutions to have loans. However, in the end of June 2015, Chengdu Agricultural Bank, the village banks and other financial institutions provide the credit financial support of 1576.5 million yuan to about 66 rural land stock cooperatives in Chongzhou through rural property mortgage and the loans of agricultural professional managers, etc. In this process, the loans of the agricultural professional managers are 13,125,000 yuan, involving more than 60 cooperatives. With the cooperatives as the main body, the loans of land contract management right mortgage financing are 2.55 million yuan, involving 5 cooperatives [4].

\section{B. Lack of Managers Professional Talents}

In May 2010, the first Land management rights shares cooperatives - Yangliu land shares cooperative was established in Chongzhou. By the end of 2016, there were 246 land shares cooperatives in Chongzhou. And it operated 52000 acres land, accounting for $53.8 \%$ of the total area of the city's arable land. The operating rate of the city's grain scale is over 70\% [5]. With the continuous expansion of the scale of operation, cooperatives carry out meticulous operation and management on on the cultivated land. The requirements are higher and higher. The problem of lacking of the managers and the professionals began to highlight in this process. It mainly shows that the the age structure and knowledge structure of the existing agricultural professional managers can not fully meet the requirements of cooperatives.

There is a statistical data on agricultural professional managers in Chongzhou. And the agricultural professional managers who are 45-year-old accounts for $66 \%$. And the agricultural professional managers who are in 35- year-old to 45-year-old accounts for $21 \%$. And the agricultural professional managers who are 35-year-old accounts for only $13 \%$. The percent of agricultural professional managers who have junior high school education accounts for $62 \%$. The percent of agricultural professional managers who have high school education accounts for $28 \%$. The percent of agricultural professional managers who are in college and above education accounts for only $10 \%$.

In addition, the knowledge of production skills is generally rich from the perspective of knowledge structure of agricultural professional managers. However, there is no deep understanding of modern agricultural production management, marketing, team coordination, resource integration and risk prevention and other aspects of knowledge.

It can be seen that the age structure of agricultural professional managers in Chongzhou is too large. The education level is low and the knowledge structure is single, which is not conducive to the long-term stable development of land shares cooperatives.

\section{THE COUNTERMEASURES OF DIFFICULTIES IN THE DEVELOPMENT OF AGRICULTURE CO-OPERATION SYSTEM IN CHONGZHOU}

\section{A. The Solution of the Financial Difficulties}

1) Cooperatives: to carry out the standardized construction: Land shares cooperatives should optimize the internal charter, improve the decision-making mechanism, standardize the organization. According to carrying out the system of congress, board of directors and supervisory board, it assures the cooperative information symmetry and information open. And then it should establish a more scientific and standardized financial management system to achieve the docking with the bank credit requirements. It gives full play to the functions of the congress to enhance internal democratic decision-making and democratic management. And it also improves decision efficiency. In addition, it should make the training on the legal awareness, accounting knowledge, modern finance and management knowledge, modern agricultural knowledge and other aspects of training for the cooperative managers and agricultural professional managers. It can improve the cooperative management ability of cooperatives.

2) Banks: to optimize and innovate credit products: The bank should strengthen the investigation on the rule of fund demand of land management rights shares cooperatives, and hackling the process of optimizing the credit approval. In the effective control of the risk, the bank should make the overall co-financing of the land shares cooperatives in the production, processing, storage, sales and other 
comprehensive financing needs combining with the development of the modern agricultural industry. And it should innovate the ways of guarantee to carry out land management rights, ownership of agricultural production facilities, forest (bamboo, fruit) rights, rural collective assets equity and other rural property portfolio loans to better meet the funding needs of the land shares cooperatives.

3) Government: to increase policy support: It should establish and improve the transfer service system of rural property rights, also should give full play to the county rural property rights trading center to provide "one-stop" service. It improves the rural property mortgage financing risk sharing mechanism, develops the details of using the rural property mortgage financing risk fund, and establish a supplementary mechanism. [6] It further expands the scope of policy-based agricultural insurance and guides commercial insurance. It also needs to support the guarantee companies' growth of local agricultural property to ensure that its financial support for new agricultural management plays a full role in developing rural property mortgage insurance business. It needs to establish a financial subsidy system to give interest to the shares cooperatives, such as the rural property rights as collateral, the development of vegetables, grain and oil and other farming industry. It should gradually cultivate the professional team of rural property rights assessment, establish the value evaluation system for scientific and comprehensive assessment of rural property rights to provide a scientific basis.

\section{B. Measures to Solve the Scarcity of Managers and the Professionals}

1) Expand the training content and optimize the knowledge structure of agricultural professional managers: The main task of agricultural professional managers is not to produce but to manage. Therefore, in the training of agricultural professional managers, it should transfer to the training of comprehensive skills from the past training that emphasis on a single agricultural production technology. It should make the training of modern enterprise management philosophy, team awareness, risk awareness, market awareness, communication and coordination skills and resource integration capabilities for agricultural professional managers [7].

In addition, the training should strengthen the cooperation with agricultural research institutions. And it should transfer the latest scientific research into training content timely. And then, it can strengthen the cooperation with professional training institutions to enhance the standardization of the training.

2) to broaden the training objects, and achieve the elite and younger of agricultural professional managers: At present, the professional managers of Chongzhou are mainly from village cadres and large growers. However, with the increasing demand of professional managers and the improvement of quality requirements, it is necessary to broaden the sources of agricultural professional managers. In the future, college student village official, migrant workers, agricultural and forestry vocational college graduates, urban residents, demobilized soldiers and other people familiar with agricultural production management, it should do the training on those who are interested in joining the agriculture. And then, added to the agricultural professional managers team, it can achieve the elite and younger of agricultural professional managers.

3) to strengthen the incentive and security mechanisms, and stabilize the agricultural professional managers team: The sustainable development of land shares cooperatives requires a stable and highly qualified team of agricultural professional managers. To strengthen the incentive and protection mechanism is to attract and retain high-quality professional managers.

Cooperatives can learn from the industrial and commercial enterprises. It can establish a plan that the professional managers can hold the shares of the cooperatives. So, the agricultural professional managers and cooperatives form a community of interests. The agricultural professional managers only need to establish long-term business objectives to ultimately improve their own income through promoting the sustainable development of cooperatives to improve the operating efficiency of cooperatives.

At the same time, cooperatives should also improve the system of old-age insurance, medical insurance and unemployment insurance payment for these agricultural professional managers. According to lifting the agricultural professional managers' worries, they are willing to engage in agricultural production and management in rural areas.

\section{CONCLUSION}

In Chongzhou, the agricultural co-operation system adheres to and implements the collective system of ownership, family contract system. It achieves the goal of accelerating the construction of new agricultural management system. It optimizes the allocation of agricultural resources, promotes the intensification, organization and socialization of modern agricultural production and management. It also enhances the ability of sustainable development of agriculture. And it is conducive to promoting farmers' income. It provides a useful reference in solving the issues concerning agriculture, countryside and farmers.

\section{REFERENCES}

[1] General Office of the CPC Central Committee, State Council General Office. "On the improvement of splitting rural land ownership right and contract right" [Z] .2016.

[2] Wang Maolin. Study on the Efficiency and Factors of Land Share Cooperative in Chongzhou [D]. Chengdu: Sichuan Agricultural University, 2015.

[3] Hu Xiaoshan. Study on the Performance of Land Stock Cooperative System in Chongzhou[D]. Chengdu: Sichuan Agricultural University, 2013. 
[4] Men Xiuqin. The Practical Exploration of Quantitative Reform of Financial Support for Agricultural Funds in Chongzhou[N]. Journal of the Party Committee of the Communist Party of China, 2015 (6): $55-58$.

[5] http://www.scagri.gov.cn/ywdt/hydt/201705/t20170517_510372.html )

[6] Pu Dan. Financial innovation to support the research on rural land joint-stock cooperatives [J]. Rural Finance, 2016 (1).

[7] Li Zhirong. Study on the professional competence of professional managers of farmer 's professional cooperatives [J]. Human Resource Management, 2011 (4): 178-180. 